\title{
Cultural methods for establishing Wyoming big sagebrush on mined lands
}

\author{
G.E. SCHUMAN, D.T. BOOTH, AND J.R. COCKRELL
}

\begin{abstract}
Authors are soil scientist/research leader and rangeland scientist, USDA, ARS, Rangeland Resources Research Unit, High Plains Grassiands Research Station, 8408 Hildreth Road, Cheyenne, Wyo. 82009 and graduate research assistant, Plant, Soil, and Insect Sciences Dept., University of Wyaming, Laramie, Wyo. 82071 .
\end{abstract}

\begin{abstract}
Wyoming big sagebrush (Artemisia tridentata ssp. wyomingensis Beetle \& Young) is one of the most widely distributed shrub species in Wyoming and the Rocky Mountain and Northern Plains region. Its reestablishment on mined lands has generally proven difficult however, because of low seedling vigor, an inability to compete with herbaceous species, poor seed quality, and altered edaphic conditions. Field research evaluating the effect of topsoil management, mulching practice, and plant competition have shown that all of these factors significantly influence initial sagebrush establishment. Greater sagebrush establishment occurred on fresh topsoil compared to 5-year-old stockpiled topsoil. Stubble, surface-applied mulch, and elimination of herbaceous competition also significantly increased establishment in the first growing season. A cool, wet second-year growing season (April-September) resulted in large increases in sagebrush seedling density across all treatments; however, soil management and competition treatment effects were still apparent in the second year. Mulch type had limited effects on sagebrush seedling density by the third year of the study. This research indicates that big sagebrush seed viability in the soil is longer than previously thought and that seed dormancy, safe site development, and climactic conditions play important roles in germination, establishment, and seedling survival of this species.
\end{abstract}

Key Words: topsoil, mulching, plant competition, VAM, topsoil storage

Wyoming big sagebrush (Artemisia tridentata Nutt ssp. wyomingensis Beetle \& Young) occurs across the Western United States and east to the Black Hills (Beetle and Johnson 1982). Although controversy exists over its value (Colbert and Colbert 1983, Tessman and Kleinman 1989), the mining industry is

The authors express their appreciation to Dr. E.J. DePuit for his part in the preparation of the grant proposal. This work was supported in part by the Abandoned Coal Mine Lands Research Program at the University of Wyoming. This support was administered by the Wyoming Department of Environmental Quality from funds returned to Wyoming from the Office of Surface Mining of U.S. Department of Interior. The authors also express their appreciation to Dr. Gary V. Richardson, Statistician for his assistance in experimental design and data analysis and to Scott Belden, Environmental Coordinator, North Antelope Coal Company for his cooperation and assistance. We also want to express our appreciation to Larry Griffith, Pam Freeman, Chris Mahelona, Ernie Taylor, and Matt Mortenson for their technical assistance.

Manuscript accepted 17 May 1997. encouraged or required to restore big sagebrush on mined lands if it existed in the pre-mined ecosystem (Wyoming Dept. Environ. Quality 1996). Establishment of big sagebrush on reclaimed mined lands can be accomplished by direct secding or by transplanting. Luke and Monsen (1983) found that direct seeding was the most cost effective method, however, the reliability of direct seeding for shrub reestablishment was not good. Many theories exist as to the reasons for poor establishment of big sagebrush from direct seeding, including poor seed viability (Harniss and McDonough 1976, Young and Evans 1989), seed dormancy, and poor seedbed microclimate (McDonough and Harniss 1974, Meyer and Monsen 1992).

Herbaceous species competition may also contribute to the variable success rate of direct seeded sagebrush. Blaisdell (1949) reported that grasses were more competitive than sagebrush when seeded from 2 years before to 1 year after seeding sagebrush. Jones (1991) was able to show increased survival of big sagebrush by removing vegetative competition. Cook and Lewis (1963) and Sturges (1977) noted that competition effects were probably related to the sagebrush seedlings' inability to compete for water. Another factor that might reduce sagebrush seedling survival is the lack of, or reduced level of vesicular-arbuscular mycorrhizae (VAM) inoculum present in the post-mining soil. Soil salvage and storage can greatly influence the level of VAM inoculum present (Allen and Allen 1980, Smith et al. 1987, Rives et al. 1980, Gould and Liberta 1981, Williams et al. 1981, Persson and Funke 1988, Christensen and Allen 1979, Douds and Schenck 1991). Topsoil salvage can result in mixing of soil horizons, altered edaphic conditions, and dilution or reduction of inoculum levels (DePuit 1988, Stahl et al. 1988, White et al. 1989). Storing (stockpiling) topsoil reduces the VAM inoculum potential of the soil even when stockpiled for as little as 6 months (Allen and Allen 1980, Smith et al. 1987, Williams et al. 1981, Persson and Funke 1988). Most rangeland shrubs form VAM associations and some, including big sagebrush, are often considered to be obligately mycorrhizal (Allen 1982). Call and McKell (1981) reported greater shoot growth from inoculated sagebrush seedlings than from those not inoculated. VAM associations result in improved nutrient uptake, especially phosphorus (Sylvia and Williams 1992), and improved resistance to drought in maize (Sylvia et al. 1993).

The objectives of this research were to evaluate sagebrush establishment and survival relative to; (1) the efficacy of directapplied topsoil, (2) the value of various mulch types, and (3) competition from concurrently seeded perennial grasses. 


\section{Field Site and Methods}

The research was conducted at the North Antelope Coal Mine, in Campbell County, approximately $100 \mathrm{~km}$ south of Gillette, Wyo. The site has a cool, semiarid-continental climate. Precipitation ranges from 250 to $330 \mathrm{~mm}$ annually, with approximately $70 \%$ occurring from April through August. Monthly mean temperatures range from a low of $-5^{\circ} \mathrm{C}$ in January to a high of $22.5^{\circ} \mathrm{C}$ in July. The fresh topsoil was composed of a complex of the Shingle (loamy, mixed, calcareous, mesic , shallow, Ustic Torrorthents) and Samsil series (clayey, montmorillinitic, calcareous, mesic, shallow, Ustic Torrorthents). The stockpiled topsoil came from an area that was mapped a Bidman-Briggsdale complex. Both the Bidman and Briggsdale series are fine, montmorillinitic, mesic, Ustollic Paleargids. The topsoil was stockpiled in a large (10-15 $\mathrm{m}$ high) mound constructed by scrapers and seeded to a mixture of native cool-season perennial grasses.

The project was initiated in August 1990 on approximately 1.2 ha of leveled coal mine spoil. Treatments included: (1) topsoil management; a) fresh stripped or b) stockpiled topsoil that had been stored for 5 years; (2) mulch type; a) stubble mulch, b) surface-applied straw mulch that was crimped, c) stubble and sur- face applied straw, and d) no mulch; and (3) competition; a) no perennial grass seeded, b) $16 \mathrm{~kg}^{\text {PLS ha }} \mathrm{h}^{-1}$ of perennial grass, and c) $32 \mathrm{~kg}$ PLS ha' ${ }^{-1}$ of perennial grass seeded. Each topsoil-treatment plot was 15 by $60 \mathrm{~m}$ with mulch subplots being 15 by $15 \mathrm{~m}$ and competition sub-subplots being 15 by $5 \mathrm{~m}$. All treatments were assigned at random in a randomized block, split-split plot design with 3 replications (Fig. 1). The plots were established in August 1990 and topsoil placed on the regraded and ripped spoil material. Topsoil replacement depth averaged $30 \mathrm{~cm}$ and was accomplished in September 1990. Since the entire stockpile was utilized in the study; efforts were made to ensure that topsoil from the various levels of the stockpile was placed on all plots. All plots were ripped and disked to relieve compaction, mix the various lifts of topsoil, and prepare the seedbed.

Baseline topsoil $(0-30 \mathrm{~cm})$ and spoil (surface $15 \mathrm{~cm}$ of spoil) samples were collected in April 1991. These samples were analyzed for electrical conductivity (EC) (Rhoades 1982); calcium, magnesium, sodium, and potassium (Rhoades 1982); total Kjeldahl nitrogen (TKN) (Schuman et al. 1973); sodium bicarbonate-extractable phosphorus (Olsen et al. 1954); and cation exchange capacity. (U.S. Salinity Laboratory Staff 1954). Vesicular-arbuscular mycorrhizal spore levels were assessed using sucrose floatation methods and counting (Allen et al. 1979).

\begin{tabular}{|c|c|c|c|c|c|c|c|c|}
\hline \multicolumn{3}{|c|}{$\underset{\text { Rep }}{\text { Rep }}$} & \multicolumn{4}{|c|}{$\begin{array}{c}\text { Rep } \\
\|\end{array}$} & \multicolumn{2}{|c|}{$\begin{array}{c}\text { Rep } \\
\text { III }\end{array}$} \\
\hline 1 stubble & 1 & stubble & 2 & stubble & 2 & & 3 & 3 \\
\hline 3 surface & 3 & surface & 3 & $\begin{array}{l}+ \\
\text { surfece }\end{array}$ & & $\begin{array}{l}\text { stubble } \\
\text { mulch }\end{array}$ & $\begin{array}{ll}1 & \begin{array}{c}\text { stubble } \\
\text { mulch }\end{array}\end{array}$ & $\begin{array}{c}1 \text { surface } \\
\text { mulch }\end{array}$ \\
\hline 2 mulch & 2 & mulch & 1 & mulch & 1 & & 2 & 2 \\
\hline 2 & 2 & & 3 & & 3 & $\begin{array}{l}c \\
0\end{array}$ & 3 & $\begin{array}{ll}3 & 6 \\
& 0\end{array}$ \\
\hline $3 \begin{array}{c}\text { stubble } \\
\text { mulch }\end{array}$ & & $\begin{array}{l}\text { surface } \\
\text { mulch }\end{array}$ & 2 & $\begin{array}{l}\text { surface } \\
\text { mulch }\end{array}$ & 2 & $\begin{array}{l}n \\
t \\
r\end{array}$ & $2 \begin{array}{c}\text { surface } \\
\text { mulch }\end{array}$ & $\begin{array}{ll}2 & 1 \\
& 1\end{array}$ \\
\hline 1 & 1 & & 1 & & 1 & $\begin{array}{l}0 \\
1\end{array}$ & 1 & $\begin{array}{ll}1 & 0 \\
1 & 1\end{array}$ \\
\hline $\begin{array}{l}C \\
0\end{array}$ & 1 & & 1 & & 1 & & 1 & 1 stubble \\
\hline$t$ & & $\begin{array}{l}\text { stubble } \\
\text { mulch }\end{array}$ & 2 & $\begin{array}{l}\text { stubble } \\
\text { mulch }\end{array}$ & & $\begin{array}{l}\text { surface } \\
\text { mulch }\end{array}$ & 2 & $2 \begin{array}{cc}+ \\
\text { surface }\end{array}$ \\
\hline$\stackrel{0}{1}$ & 3 & & 3 & & 3 & & 3 & 3 mulch \\
\hline 3 & 3 & $\begin{array}{l}c \\
0\end{array}$ & 2 & c & 2 & stubble & $2 \quad$ stubble & 2 \\
\hline $2 \begin{array}{c}\text { sufface } \\
\text { mulch }\end{array}$ & 2 & t & 1 & t & 1 & $\begin{array}{c}t \\
\text { surface }\end{array}$ & $\begin{array}{cc}3 & + \\
& \text { surface }\end{array}$ & $3 \begin{array}{c}\text { stubble } \\
\text { mulch }\end{array}$ \\
\hline 1 & 1 & $\begin{array}{l}0 \\
1\end{array}$ & 3 & $\begin{array}{l}0 \\
1\end{array}$ & 3 & mulch & 1 mulch & 1 \\
\hline STS & & FTS & & FTS & & STS & FTS & STS \\
\hline
\end{tabular}

Grass Seeding Rate:

FTS $=$ fresh topsoil

$1=0 \mathrm{~kg} \mathrm{PLS} /$ hectare

STS $=$ stockpiled topsoil

$2=16 \mathrm{~kg}$ PLS/hectare

$3=32 \mathrm{~kg}$ PLS /hectare

Fig. 1. Field plot diagram of the Wyoming big sagebrush establishment study, North Antelope Coal Co., Gillette, Wyo. 
In late April 1991, 'Steptoe' barley (Hordeum vulgare) was seeded at $60 \mathrm{~kg} \mathrm{ha}^{-1}$ on the plots which had been assigned the stubble mulch or stubble + surface applied straw mulch treatments. In mid-July 1991 the barley was clipped to reduce seed maturation and subsequent year competition from volunteer barley plants. Annual weeds on the other mulch treatment plots were controlled with $0.55 \mathrm{~kg} \mathrm{ha}^{-1}$ glyphosate [ $\mathrm{N}$-(phosphonomethyl) glycine] and tillage.

In late November 1991, the competition treatments were imposed by drill seeding a mixture of 'Rosanna' western wheatgrass [Pascopyrum smithii (Rybd.) A. Love], 'San Luis' slender wheatgrass [Elymus trachycaulus (Link) Gould ex Skinners], and 'Critana' thickspike wheatgrass [Elymus lanceolatus (Scribner \& J.G. Smith) Gold] composed of equal seed numbers of each of the grasses. Grass was seeded after soil temperatures had dropped below that conducive to germination. The competition sub-subplots were seeded at 0,16 , or $32 \mathrm{~kg}$ PLS ha ${ }^{-1}$. After seeding the grass mixture, wheat (Triticum aestivum) straw was added at $1,000 \mathrm{~kg} \mathrm{ha}^{-1}$ to the stubble + surface mulch treatment and anchored to the surface with a vertical disk crimper. Wheat straw, at the rate of $4,500 \mathrm{~kg} \mathrm{ha}^{-1}$, was also applied and anchored to the soil surface of the surface mulch treated plots. Surface mulch was applied after grass seeding was done to ensure good seed placement depth control and eliminate big sagebrush seed burial by the crimping process.

In early March 1992, all plots were broadcast seeded with sage-

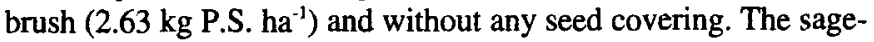
brush was seeded at this time to reduce the potential for spurious germination during the winter if surface temperatures were adequate and to reduce the length of time seed might be displaced by wind. Rice hulls were mixed with the sagebrush seed to improve seed flow. The sagebrush seed was collected in the Powder River Basin area of Wyoming in early December 1991 and threshed with a debearder (Booth, et al. 1995). No grass seedling emergence had occurred when the sagebrush was seeded.

In late March 1992, six 1- $\mathrm{m}^{2}$ quadrats were established in each mulch by grass competition (15-X 5-m) subplot, for a total of 144 quadrats per replication. The quadrats were established in 2 belts of 3 quadrats with each belt lying in an east-west direction. The belts were systematically established $1 \mathrm{~m}$ from the edge of each subplot. The belts and quadrats were established prior to seedling emergence to prevent bias in their location. After completing the June 1992 sagebrush seedling counts it was determined that an additional 3 quadrats were needed to achieve sample adequacy of the system. Therefore, 3 additional quadrats were located within the belt between the other 6 quadrats and sagebrush and grass seedlings counted. These quadrats ( 216 per replication; 648 total) were used to assess grass and sagebrush seedling numbers in 1992, and sagebrush seedling numbers in 1993 and 1994. Grass seedling numbers were not assessed after 1992 because of the difficulty of distinguishing individual plants from new culms. Sagebrush seedling numbers were evaluated in June and October 1992 and 1993, and in September 1994.

Topsoil samples $(0-7.5 \mathrm{~cm})$ were taken every $2-3$ weeks, in each subplot of 1 replication, throughout the growing season in 1992 to evaluate the effects of the treatments on soil moisture. Two samples were collected from each subplot and averaged to represent the subplot.

In June of 1993, sagebrush seedlings located outside of the quadrats were excavated, their roots fixed and stained to evaluate percentage mycorrhizal infection (Kormanick and McGraw 1982; Giovenetti and Mosse 1980).

Many of the quadrats had no sagebrush seedlings present, particularly in the spring and fall 1992 seedling counts. Analysis of variance was accomplished on the sagebrush seedling means of the 9 quadrats collected on cach replicate sub-subplot. This is a conservative evaluation of the data; therefore, it strengthens interpretations resulting from any statistical differences observed. The data were analyzed as a split-split plot design. The main plots were fresh and stockpiled topsoil and the 4 mulch types were randomly assigned as subplots within each topsoil source. The 3 herbaceous species competition treatments were randomly assigned to sub-subplots within each of the mulch subplots (Fig.1). Fisher's Protected LSD was used to separate treatment means. All statistical comparisons were evaluated at $\mathrm{P} \leq 0.10$.

\section{Results and Discussion}

Baseline chemical and nutrient parameters showed the fresh topsoil to have significantly higher concentrations/values for most of the parameters measured (Table 1). Topsoil stockpiling did not have as great an effect on edaphic properties as reported by others (DePuit 1988; White et al. 1989). The lack of more pronounced effects of stockpiling on topsoil chemical properties may be due in part to the fact that the stockpile was seeded to perennial grass. This practice ensures greater soil permeability, enhances soil biological functions through the contribution of plant carbon to the soil system, and general improved soil physical qualities.

Table 1. Chemical and nutrient concentrations in fresh and stockpiled topsoil.

\begin{tabular}{|c|c|c|c|c|c|c|c|}
\hline Soil Mgmt & $\mathrm{Ca}^{++}$ & $\mathrm{Mg}^{++}$ & $\mathrm{Na}^{+}$ & $\mathrm{K}^{+}$ & TKN & $\mathbf{P}$ & CEC \\
\hline & $\cdots$ & . & (mg & T. & 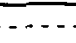 & 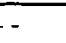 & (me $100 \mathrm{~g}^{-1}$ ) \\
\hline Fresh & $342 a$ & $108 a$ & $79 a$ & $23 \mathrm{~b}$ & $950 \mathrm{a}$ & $7.2 \mathrm{a}$ & $23.0 \mathrm{a}$ \\
\hline Stockpiled & $170 \mathrm{~b}$ & $67 \mathrm{~b}$ & $84 a$ & $26 a$ & $740 \mathrm{~b}$ & $6.3 b$ & $10.9 b$ \\
\hline
\end{tabular}

Values within a column with the same letter are not significantly different, $P \leq 0.10$.

Sagebrush seedling densities exhibited a significant 3-way interaction (topsoil management $\times$ mulch type $\times$ grass competition) for all 5 dates of sagebrush seedling density measurements (Tables 2-4). Sagebrush seedling densities exhibited different treatment responses in the spring 1992, fall 1992, and spring 1993 compared to in the fall 1993 and 1994 . We believe the large increase in seedling density that occurred between June 1993 and October 1993 reflects the wet and cool spring and summer of 1993 (Table 5) and continued viability of the sagebrush seed. Precipitation in 1993 was almost double that in 1992 and 1994 and the April through June average monthly temperature was about $2^{\circ} \mathrm{C}$ cooler than 1992 . The sagebrush seedling densities measured in 1992 on the fresh topsoil, no competition, mulched treatments exceeded (Table 2) the recently established shrub density standard of 1 shrub $\mathrm{m}^{-2}$ for Wyoming (Wyoming Dept. Environ. Quality 1996). This emphasizes the importance of good cultural practices especially since these seedling densities were achieved during a below average ( $87 \%$ of average) precipitation year. Precipitation in 1994 was also below average (85\% of average). Fresh topsoil had $>40 \%$ more sagebrush seedlings than 
Table 2. Sagebrush seedling density as affected by topsoil,management, mulch type, and grass seeding rate, 1992.

\begin{tabular}{|c|c|c|c|c|c|c|}
\hline \multirow[b]{3}{*}{$\begin{array}{l}\text { Competition } \\
\left(\mathrm{kgPLS} \mathrm{ha}^{-1}\right)\end{array}$} & \multirow[b]{3}{*}{0} & \multicolumn{5}{|c|}{ Topsoil Management } \\
\hline & & \multicolumn{2}{|c|}{ Fresh } & \multicolumn{3}{|c|}{ Stockpiled } \\
\hline & & 16 & 32 & 0 & 16 & 32 \\
\hline \multicolumn{7}{|l|}{ Mulch Type } \\
\hline \multicolumn{7}{|c|}{$\begin{array}{l}\text { Spring } 1992 \\
\left.\text { Splants } \mathrm{m}^{-2}\right)\end{array}$} \\
\hline stubble & 5.78 & 1.11 & 0,04 & 0.11 & 0 & 0 \\
\hline surface & 7.37 & 0.07 & 0 & 0.04 & 0 & 0 \\
\hline $\begin{array}{l}\text { stubble + } \\
\text { surface }\end{array}$ & 1.59 & 1.56 & 0.63 & 0.11 & 0 & 0.04 \\
\hline control & 0 & 0 & 0.04 & 0 & 0 & 0 \\
\hline
\end{tabular}

$\mathrm{LSD}_{0.10}=\mathbf{2 . 4 8}$ within a mulch type with a topsoil managemenr;

$\mathrm{LSD}_{0.10}=2.51$ within a topsoil management with a seeding rate;

$\operatorname{LSD}_{0.10}=2.71$ within a mulch type within a seeding rate.

\begin{tabular}{lrrrrrr} 
& \multicolumn{7}{c}{ Fall 1992 } & & 0 & 0.04 \\
stubble & 5.15 & 0.52 & 0.07 & 0 & 0 & 0 \\
surface & 6.07 & 0 & 0.15 & 0 & 0 & \\
stubble + & & & & & & \\
surface & 1.41 & 1.11 & 0.37 & 0.30 & 0.04 & 0 \\
control & 0 & 0 & 0 & 0 & 0 & 0 \\
\hline
\end{tabular}

$L S D_{0.10}=2.13$ within a mulch type within a topsoil management;

$\mathrm{LSD}_{0.10}=2.16$ within a topsoil management within a seeding rate;

$\operatorname{LSD}_{0.10}=2.30$ within a mulch type within a seeding rate.

stockpiled topsoil and in 1992 and spring 1993, the differences were generally 1-2 orders of magnitude greater for the fresh topsoil treatment. Soil moisture content of the surface $7.5 \mathrm{~cm}$ of the fresh topsoil was always higher than that observed in the stockpiled topsoil (Fig. 2). This consistently higher soil moisture in the fresh topsoil undoubtedly accounted for a portion of the observed greater sagebrush seedling establishment in the fresh topsoil treatment in 1992. The differences in sagebrush seedling densities between topsoil management treatments were generally greatest

Table 3. Sagebrush seedling density as affected by topsoil management, mulch type, and grass seeding rate, 1993.

\begin{tabular}{|c|c|c|c|c|c|c|}
\hline \multirow[b]{3}{*}{$\begin{array}{l}\text { Competition } \\
\left(\mathrm{kgPLS} \mathrm{ha}^{-1}\right)\end{array}$} & & \multicolumn{5}{|c|}{ Topsuil Management } \\
\hline & \multirow{3}{*}{0} & \multicolumn{2}{|c|}{ Fresh } & \multicolumn{3}{|c|}{ Stockpiled } \\
\hline & & 16 & 32 & 0 & 16 & 32 \\
\hline \multicolumn{6}{|l|}{ Mulch Type } & \\
\hline & & & (p) & $\left.\mathrm{n}^{-2}\right)-$ & & - \\
\hline \multicolumn{7}{|c|}{ Spring 1993} \\
\hline stubble & 6.30 & 2.04 & 1.81 & 1.63 & 0.04 & 0.15 \\
\hline surface & 8.74 & 0.30 & 0.89 & 0.44 & 0.04 & 0.93 \\
\hline surface & 4.07 & 2.48 & 1.52 & 1.56 & 0.33 & 0.11 \\
\hline control & 1.26 & 0.56 & 0.22 & 0.37 & 0.14 & 0.04 \\
\hline
\end{tabular}

$\mathrm{LSD}_{0.10}=2.01$ within a mulch type williul a topsoil management;

$\mathrm{LSD}_{0.10}=2.07$ within a topsoil management within seeding rate;

$\mathrm{LSD}_{0.10}=2.73$ within a mulch type within a seeding rate.

\begin{tabular}{lrrcccc} 
& \multicolumn{7}{c}{ Fall 1993 } \\
stubble & 9.67 & 3.93 & 2.93 & 5.41 & 2.11 & 1.93 \\
surface & 13.48 & 1.00 & 1.22 & 2.74 & 1.81 & 2.18 \\
stubble + & & & & & & \\
surface & 8.04 & 2.89 & 1.63 & 4.59 & 2.15 & 1.70 \\
control & 7.52 & 1.37 & 0.52 & 1.81 & 0.52 & 0.19 \\
\hline
\end{tabular}

$\mathrm{LSD}_{0.10}=2.59$ within a mulch type within a topsoil management;

$\mathrm{LSD}_{0.10}=2.89$ within a topsoil management within a seeding rate;

$\operatorname{LSD}_{0.10}=3.91$ within a mulch type within a seeding rate.
Table 4. Sagebrush seedling density as affected by topsoil management, mulch type, and grass competition, Fall 1994.

\begin{tabular}{|c|c|c|c|c|c|c|}
\hline \multirow[b]{3}{*}{$\begin{array}{l}\text { Competition } \\
\left(\mathrm{kgPLS}{ }^{1}\right)\end{array}$} & \multirow[b]{3}{*}{0} & \multicolumn{5}{|c|}{ Topsoil Management } \\
\hline & & \multicolumn{2}{|c|}{ Fresh } & \multicolumn{3}{|c|}{ Stockpiled } \\
\hline & & 16 & 32 & 0 & 16 & 32 \\
\hline \multicolumn{7}{|l|}{ Mulch Type } \\
\hline & & $\cdots$ & -1 pla & $\left.n^{-2}\right)$ & - & $\ldots$ \\
\hline stubble & 8.15 & 9.82 & 7.11 & 3.44 & 2.78 & 3.26 \\
\hline surface & 12.11 & 4.63 & 5.33 & 2.40 & 3.52 & 5.07 \\
\hline stubble & & & & & & \\
\hline surface & 9.11 & 3.78 & 4.26 & 3.30 & 3.85 & 2.52 \\
\hline control & 7.22 & 5.88 & 4.56 & 4.48 & 2.52 & 1.70 \\
\hline
\end{tabular}

$\operatorname{LSD}_{0.10}=3.00$ within a mulch type within a topsoil management;

$\mathrm{LSD}_{0.10}=3.79$ within a topsoil management within seeding rate;

$\mathrm{LSD}_{0.10}=3.99$ within a mulch type within a seeding rate.

when no grass competition existed. Topsoil management effects on seedling density were never observed in the 16 and $32 \mathrm{~kg} \mathrm{ha}^{-1}$ grass seeding rate treatments. Sagebrush seedling data clearly show that topsoil source is important in sagebrush establishment, but this study has not clearly delineated all of the specific benefits to be expected from the fresh topsoil.

VAM spore numbers were $3,088 \pm 1,087$ and 4,500 $+1,525 / \mathrm{g}$ soil in the stockpiled and fresh topsoil, respectively. Even though this difference was significant $(P \leq 0.10)$ it was expected that the difference in spore numbers between the 2 topsoil sources would be much greater (Allen and Allen 1980; McMahon and Warner 1984). Mycorrhizal infection in sagebrush seedlings excavated in June 1993 from the 2 topsoil treatments was not different (Table 6 ) in spite of the difference in VAM spore levels at the initiation of the study. Loree and Williams (1984) found that native grasses became infected with VAM within a year of establishment on stockpiled topsoil indicating inoculum is spread quite readily under natural conditions. However, Stahl et al. (1996, 1997) reported that non-mycorrhizal big sagebrush seedlings exhibited significantly less soil moisture stress tolerance and all died at a soil water potential <-3.3 Mpa whereas mycorrhizal seedlings survived in soil as dry as $3.7 \mathrm{MPa}$. Therefore, non-mycorrhizal seedlings in our study may not have survived the numerous, moisture stress periods that are typical of arid/semiarid climates and

Table 5. Monthly precipitation and mean monthly temperature, North Antelope Coal Company, Gillette, Wyo., 1992-1994.

\begin{tabular}{lcccccc}
\hline \hline Month & \multicolumn{2}{c}{1992} & \multicolumn{2}{c}{1993} & \multicolumn{2}{c}{1994} \\
& Precip & Temp & Precip & Temp & Precip & Temp \\
\hline & $(\mathrm{cm})$ & $\left({ }^{\circ} \mathrm{C}\right)$ & $(\mathrm{cm})$ & $\left({ }^{\circ} \mathrm{C}\right)$ & $(\mathrm{cm})$ & $\left({ }^{\circ} \mathrm{C}\right)$ \\
Jan & 0 & -0.6 & 0 & -7.2 & 0.20 & -3.3 \\
Feb & 0.68 & 2.2 & 0.38 & -7.7 & 0.15 & -6.1 \\
Mar & 3.15 & 4.4 & 1.47 & 2.2 & 0.41 & 3.3 \\
Apr & 0.76 & 7.7 & 6.48 & 5.5 & 2.79 & 6.6 \\
May & 2.26 & 13.2 & 5.94 & 12.7 & 2.87 & 14.9 \\
Jun & 6.43 & 16.5 & 14.15 & 14.3 & 8.36 & 18.2 \\
Jul & 7.75 & 17.6 & 9.70 & 17.1 & 4.93 & 19.8 \\
Aug & 2.95 & 18.2 & 10.13 & 18.2 & 0.81 & 20.9 \\
Sep & 1.75 & 15.4 & 2.29 & 12.1 & 1.22 & 16.0 \\
Oct & 0.41 & 8.8 & 2.36 & 6.1 & 5.49 & 7.2 \\
Nov & 0.89 & -0.6 & 0.36 & -2.2 & 0.58 & 0 \\
Dec & 1.19 & -6.6 & $\underline{0.10}$ & -1.7 & $\underline{0.05}$ & -1.7 \\
Total & 28.22 & & 53.36 & & 27.86 & \\
\hline $1978-1995$ & & & & &
\end{tabular}

$1978-1995$ year average is $32.3 \mathrm{~cm}$ 


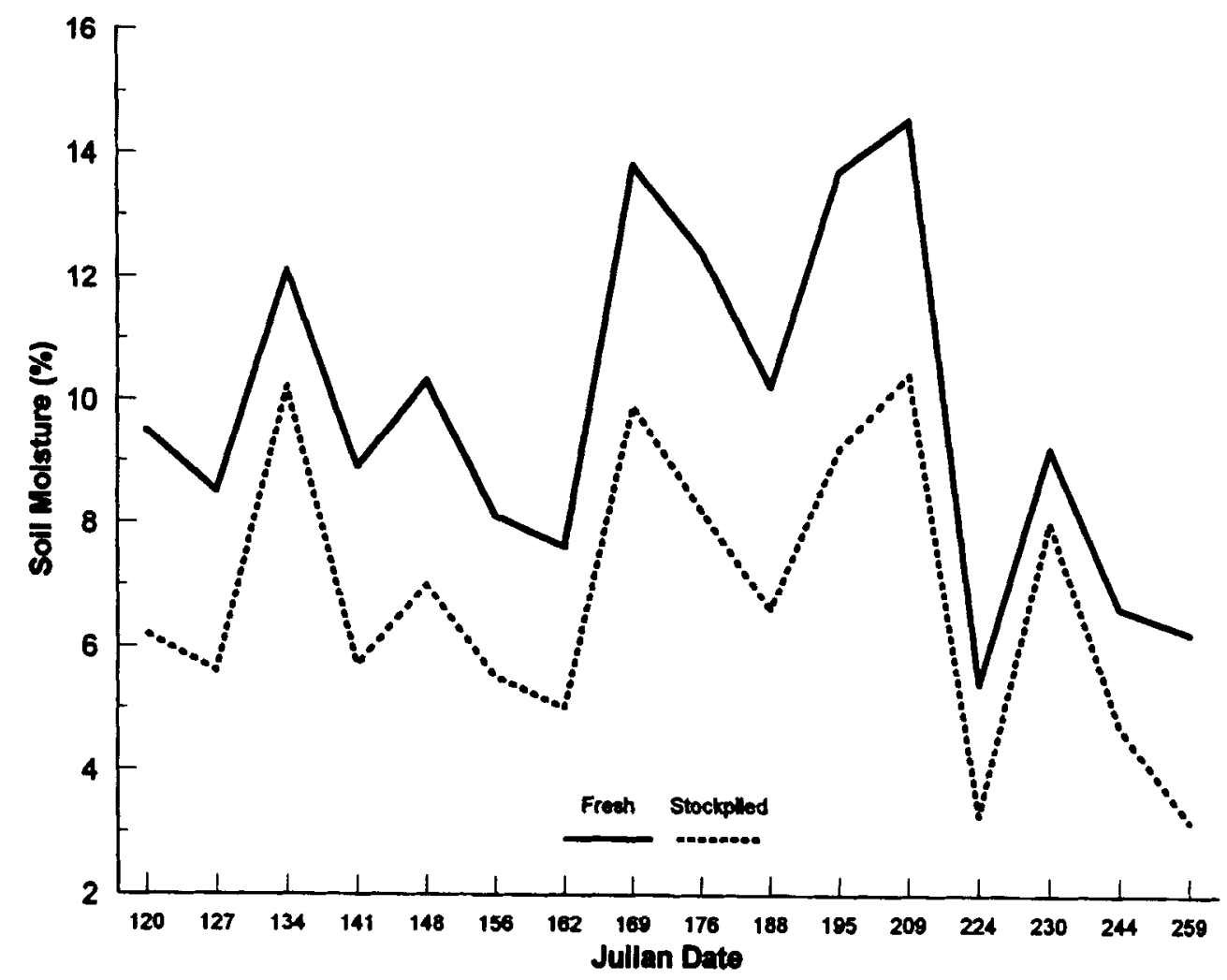

Fig. 2. Gravimetric soil moisture percentage (1992) of the fresh and stockpiled topsoil (surface $7.5 \mathrm{~cm}$ ) of Wyoming big sagebrush establishment study, North Antelope Coal Co., Gillette, Wyo.

that occurred in 1992. Our data show a decline in seedling density between June 1992 and October 1992 and we don't have a measure of seedlings that emerged between those dates. Therefore, our estimate of mycorrhizal infection could be biased upward and not represent the true population of seedlings that emerged. Further evaluation of the role of VAM on sagebrush seedling establishment will be necessary to fully assess its importance.

It appears that fresh topsoil did not act as a seedbank for the sagebrush because an adjacent companion study showed no sagebrush seedlings on unseeded, fresh topsoil during this same period (Unpublished data, D.T. Booth et al. 1994).

Mulch greatly affected sagebrush seedling establishment in 1992. No sagebrush seedlings were evident in the first year where no mulch was applied. The stubble and surface straw mulches had similar or greater sagebrush seedling densities than the combination stubble + surface mulch treatment in the 1992 sample dates. Soil moisture content of the surface $7.5 \mathrm{~cm}$ of the topsoil was greater for all mulch treatments compared to the control, where no mulch was used (Fig. 3). Stubble mulch has been shown to affect seedling microclimate through reduced diurnal temperature fluctuations and increased soil moisture (Schuman, et al. 1980). The combination stubble + surface mulch is believed to have prevented some of the sagebrush seed from reaching the soil surface resulting in germination and death or loss to other factors. The surface mulch applied to the stubble tended to give much greater ground cover than either the surface or stubble mulch alone. Seedling counts taken in the Fall 1993 and 1994 however, were not different between mulched and unmulched plots.
Grass competition reduced sagebrush seedling densities throughout the duration of the study on the fresh topsoil treatment where stubble and surface straw mulch treatments were applied and where sagebrush seedling densities were the greatest. Grass seedling numbers counted in the Fall 1992 reflect the herbaceous competition. The 0,16 and $32 \mathrm{~kg}$ PLS ha ${ }^{-1}$ grass seeding rates resulted in 0, 196, and 250 grass seedlings $m-2$ (Unpublished data, J.R. Cockrell, 1992). No differences in grass seedling densities among topsoil sources or mulch were evident.

Sagebrush seedling establishment from a single seeding over the 3 years evaluated poses numerous questions. First, did the seed sown in March 1991 remain viable 2 years and continue to germinate as "safe sites" developed and conditions became adequate for germination in 1992 and 1993? Harper (1977) states that a "safe site" is a zone or place in which a seed may reside which provides the stimuli to break dormancy, the conditions required for germination, the resources which are consumed during germination and is absent of decimating factors. Young and Evans (1989) reported that Artemisia tridentata tridentata does not maintain seed viability for more than a few months; however, Wyoming big sagebrush has been shown to have some seed dormancy (McDonough and Harniss 1974; Booth et al. 1995). Bai and Romo (1994) reported that continuous germination of seeds over time may enable fringed sage (Artemisia frigida Willd.) to occupy "safe sites" as they develop. They also concluded that germination requirements of fringed sage seed became less specific with aging. Industry reclamation specialists in the Powder River Basin of Wyoming have routinely observed increased sagebrush seedling numbers over a period of 2-3 years after seeding. 


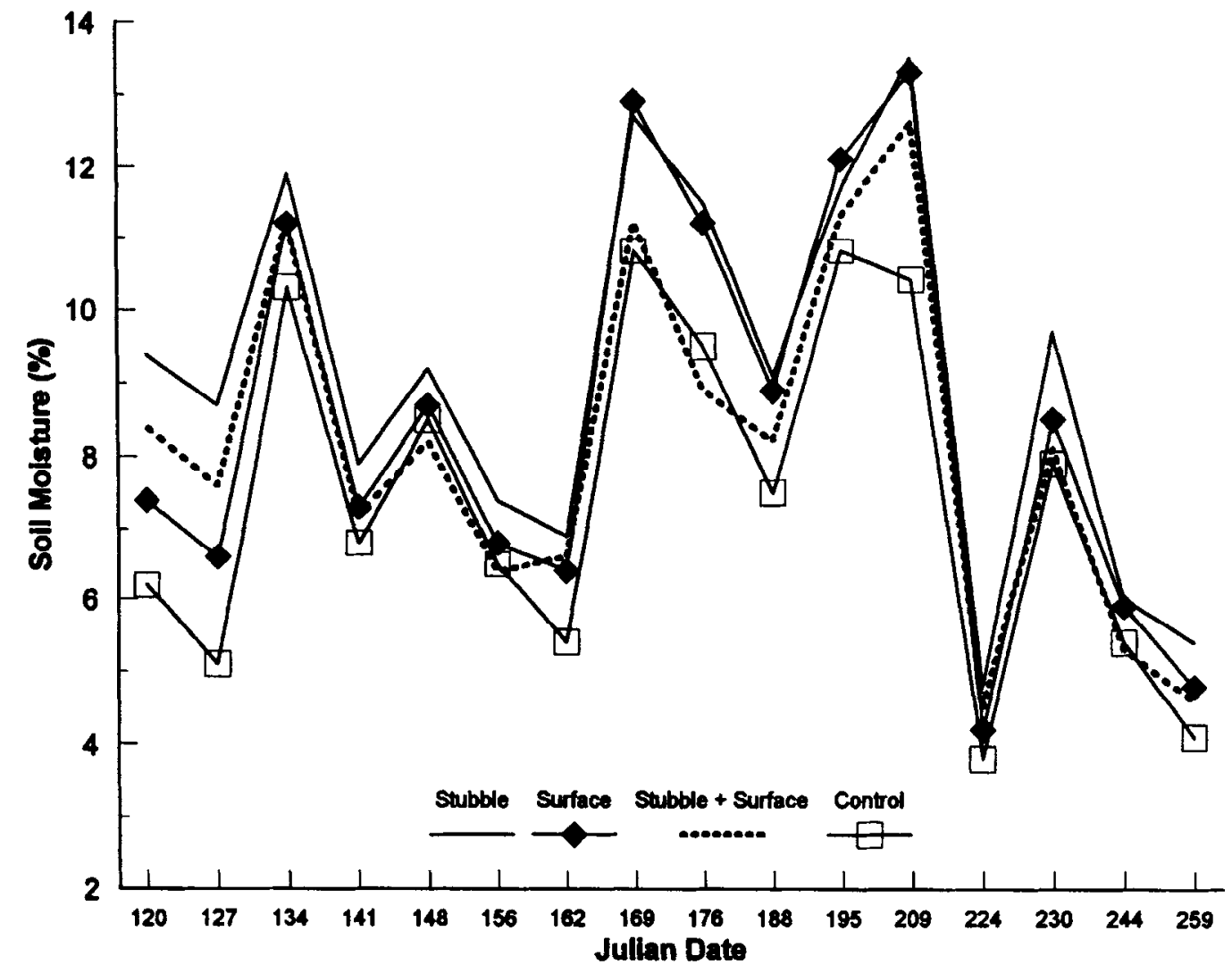

Fig. 3. Gravimetric soil moisture percentage content (1992) of the topsoil (surface $7.5 \mathrm{~cm}$ ) mulch type, Wyoming big sagebrush establishment study, North Antelope Coal Co., Gillette, Wyo.

We are confident that seed did not blow in from nearby undisturbed sagebrush-grasslands. Control plots on the adjacent study had no sagebrush seedlings develop during these 3 years. Walton et al. (1984) reviewed the subject of Artemisia reproduction strategies and concluded that seed dispersal is close to the parent and falls off sharply as distance increases. Lyford (1995) found that natural invasion of sagebrush on mined land sites was most successful when the sites were close to a seed source. In fact, he reported that natural invasion of sagebrush decreased 50 -fold when distance to the seed source exceeded $100 \mathrm{~m}$. We would, therefore, not expect significant natural invasion since our research plots were about $1 \mathrm{~km}$ from the nearest source of native sagebrush/grassland.

As noted earlier, sagebrush seedling densities observed in the third year of the study do not exhibit as much treatment response as in the first and second years. The observed sagebrush seedling densities would result in a more than adequate density of Wyoming big sagebrush for wildlife habitat needs on mined lands if one assumes that all of the seedlings survive and reach maturity; however, Kriger et al. (1987) found that $32 \%$ of big sagebrush seedlings observed the first year of a shrub-herb seeding, existed on the sitc 11 ycars latcr. Sagebrush scedling density at our research site in Fall 1994 was 5 plants $\mathrm{m}^{-2}$ when averaged across all treatments. If we assume that Kriger et al. (1987) findings are representative and that at least one-third of those plants will survive for more than 10 years, then the estimated density would be about 1.7 plants $\mathrm{m}^{-2}$, which would exceed the density standard of
1 shrub $\mathrm{m}^{-2}$ on $20 \%$ of the land area required by the Wyoming Department of Environmental Quality, Land Quality Division (1996). The same reasoning suggests the average shrub density on the stockpiled topsoil would be 1 plant $\mathrm{m}^{-2}$, which would also meet the new standard. Most of the seedlings observed in the 1994 data from our research are $>1$ yr old and can be expected to have a better survival than 1 -year-old seedlings. Survival rates may vary by location, soil characteristics, and weather patterns.

Table 6. VAM infection percentage of sagebrush seedlings as affected by topsoil management, mulch type, and grass competition.

\begin{tabular}{|c|c|c|}
\hline Treatment & Infection & $\begin{array}{l}\text { Seedlings } \\
\text { Evaluated }\end{array}$ \\
\hline & (\%) & (No.) \\
\hline \multicolumn{3}{|l|}{ Topsoil Mgmt } \\
\hline Fresh & 66 & 66 \\
\hline Stockpiled & 76 & 66 \\
\hline \multicolumn{3}{|l|}{ Mulch Type } \\
\hline Stubble & 73 & 36 \\
\hline Surface & 71 & 36 \\
\hline $\begin{array}{l}\text { Surface + } \\
\text { Stubble }\end{array}$ & 72 & 36 \\
\hline Control & 67 & 24 \\
\hline \multicolumn{3}{|c|}{$\frac{\text { Grass Competition }}{(\mathrm{kg} \mathrm{PLS} \mathrm{ha}}$} \\
\hline 0 & 73 & 69 \\
\hline 16 & 68 & 63 \\
\hline 32 & $--a$ & $--\mathbf{a}$ \\
\hline
\end{tabular}

Insufficient sagebrush seedlings available for evaluation. 
Results of this research have shown that topsoil management, mulching practices, and herbaceous species competition can influence sagebrush establishment on mined lands. Soil moisture in the surface $7.5 \mathrm{~cm}$ of the topsoil was greater in the fresh topsoil treatment compared to the stockpiled topsoil and it was also greater in all of the mulch treatments compared to the no mulch treatment. Mulching reduces the effects of rapid changes in temperature and conserves moisture in the seed site environment. Schuman et al. (1980) showed that stubble mulch further improved seed site environment over that of a surface mulch and helps create "safe sites" for seedling emergence and establishment. Fresh stripped topsoil enhances overall reclamation success because it possesses better chemical, physical, and biological properties than does stockpiled topsoil (DePuit 1988; Stahl et al., 1988; White et al., 1989). These factors influence water infiltration, water storage, nutrition, soil structure and VAM inoculum potential which enhance the potential success of plant establishment. Topsoil management to prevent or limit topsoil stockpiling should be encouraged and is generally used when mine design and development constraints are not limiting. Direct placement of topsoil is cost effective unless the mine advancement physically prevents access to those areas being reclaimed (Scott Belden, personal communication, 1996). Grass competition significantly reduced sagebrush seedling establishment and/or survival on the fresh topsoil, but not on the stockpiled topsoil treatment. Seeding practices may need to be modified where big sagebrush is an important component of the postmine plant community. These findings suggest that when sagebrush establishment is desired it might be best sown in islands or irregular shaped, small areas, with greatly reduced grass seeding rates or with no herbaceous species. These areas would need to be small and arranged so as to ensure protection of the topsoil resource from erosion and to create the greatest diversity and edge effect in the reclaimed ecosystem.

\section{Literature Cited}

Allen, M.F. 1982. Influence of vesicular-arbuscular mycorrhizae on water movement through Bouteloua gracilis (H.B.K.) lag ex Stued. New Phytol.91:191-196.

Allen, E.B. and M.F. Allen. 1980. Natural re-establishment of vesiculararbuscular mycorrhizae following strip-mine reclamation in Wyoming. J. Applied Ecology 17:139-147.

Allen, M.F., T.S. Moore, Jr., M. Christensen, and N. Stanton. 1979. Growth of vesicular-arbuscular and non-mycorthizal Bouteloua gracilis in a defined medium. Mycologia 71:666-669.

Bai, Yuguang and J.T. Romo. 1994. Germination of previously buried seeds of fringed sage (Anemisia frigida). Weed Sci. 42:390-397.

Beetle, A.A. and K.L. Johnson. 1982. Sagebrush in Wyoming. Wyoming Agr. Exp. Stn. Bull. 779, Laramie. Wyo.

Blaisdell, J.P. 1949. Competition between sagebrush seedlings and reseeded grasses. Ecol. 30:512-519.

Booth, D.T., Y. Bai, E.E. Roos 1995. Wyoming big sagebrush seed quality related to debearder operation during seed cleaning and storage. p 60-61. In: Proc. 5th International Rangeland Congress, Salt Lake City, Ut., Society for Range Management, Denver, Colo.

Call, C.A. and C.M. McKell. 1981. Vesicular-arbuscular mycorrhizae-a natural revegetation strategy for disposed processed oil shale. Recl. and Reveg. Res. 1:337-347.

Christensen, M. and M.F. Allen. 1979. Effect of VA mycorrhizae on water stress tolerance and hormone balance in native western plant species. Final Report to the Rocky Mountain Institute of Energy and Environment, Laramie, Wyo.
Colbert, T.A. and M.A. Colbert. 1983. Revegetating with sagebrush, who's right? Rangelands 5:33-35.

Cook, C.W. and C.E. Lewis. 1963. Competition between big sagebrush and seeded grasses on foothill ranges in Utah. J. Range Manage. $16: 245-250$.

DePuit, E.J. 1988. Productivity of reclaimed lands-rangeland. pp. 93-129. In: L.R. Hossner (cd.) Reclamation of Surface Mined Lands, Vol. II, CRC Press, Baco Raton, Fla.

Douds, D.D., Jr. and N.C. Schenck. 1991. Germination and hyphal growth of VAM during and after storage in soil at five matrix potentials. Soil Biol. Biochem. 23:177-183.

Giovannetti, M. and B. Mosse. 1980. An evaluation of techniques for measuring vesicular-arbuscular mycorrhizal infection in roots. New Phytol. 84:489-500.

Gould, A.B. and A.E. Liberta. 1981. Effects of topsoil storage during surface mining on the viability of vesicular-arbuscular mycorrhizal fungi. Mycologia 73:914-922.

Harniss, R.O. and W.T. McDonough. 1976. Yearly variation in germination in three subspecies of big sagebrush. J. Range Manage.29:167-168.

Harper, J.L. 1977. The recruitment of seedling populations. p. 111-147. In: Population Biology of Plants. Academic Press, New York.

Jones, G.P. 1991. Seedling survival and adult plant water relations of black sagebrush and big sagebrush in the Laramie Basin. Ph.D. Diss., University of Wyoming, Laramie, Wyo.

Kormanick, P.P. and A.C. McGraw. 1982. Quantification of vesiculararbuscular mycorrhizae in plant roots. pp. 37-45. In: N.C. Schenck (ed.) Methods and principles of mycorrhizal research. Amer. Phytopath. Soc., Minneapolis, Minn.

Kriger, J.A., W.A. Berg, J.T. Herron, C.M. Phillips, and R.G. Atkinson. 1987. Shrub establishment in the mountain shrub zone. pp. L-3-1 through L-3-6. In: Proc., 4th Biennial Symposium on Surface Mining and Reclamation of the Great Plains and 4th Annual Meeting of the Amer. Soc. Surface Mining and Reclamation, 16-20 March 1987, Billings, Mont. Reclamation Research Unit Rept. 8704, Montana State Univ., Bozeman, Mont.

Loree, M.A.J. and S.E. Williams. 1984. Vesicular-arbuscular mycorrhizae and severe land disturbance. pg 1-14. In: Proc. VA Mycorrhizae and Reclamation of Arid and Semiarid Lands. August 17-19, 1982, Dubois, Wyo. Wyoming Agr. Exp. Sta. Sci.. Rep. No. SA1261, Laramie, Wyo.

Luke, F. and S.B. Monsen. 1983. Methods and costs for establishing shrubs on mined lands in southwestern Wyoming. pp. 286-292. In: Proceedings, Symposium on the biology of Atriplex and related chenopods. USDA Forest Serv., Gen. Tech. Rep. INT-172, Ogden, Ut.

Lyford, M.E. 1995. Shrub establishment on drastically disturbed lands. M.S. Thesis, University of Wyoming, Laramie, Wyo.

McDonough, W.T. and R.O. Harniss. 1974. Effects of temperature on germination in three subspecies of big sagebrush. J. Range. Manage. 27:204-205.

McMahon, J.A. and N. Warner. 1984. Dispersal of mycorrhizal fungi: Processes and agents. pp. 28-41. In: S.E. Williams and M.F. Allen (eds.) VA mycorrhizae and reclamation of arid and semiarid lands. Univ. Wyo. Agr. Exp. Sta. Rep. AS1261, Laramie, Wyo.

Meyer, S.E. and S.B. Monsen. 1992. Big sagebrush germination patterns: Subspecies and population differences. J. Range. Manage. 45:87-93.

Olsen, S.R., C.V. Cole, F.S. Watanabe, and L.A. Dean. 1954. Estimation of available phosphorus in soils by extraction with sodium bicarbonate. USDA Circular 939, United States Government Printing Office, Washington, D.C.

Persson, T.J. and B.R. Funke. 1988. Microbiology of stored topsoil at North Dakota stripmining sites. Arid Soil Res. and Rehabil. 2:235-250.

Rhoades, J.D. 1982. Soluble salts. pp. 167-179. In: A.L. Page et al. (eds.) Methods of Soil Analysis, Part 2. Agron. Monograph 9, Amer. Soc. of Agron., Madison, Wisc.

Rives, C.S., M.E. Bajwa, A.E. Liberta, and R.M. Miller. 1980. Effects of topsoil storage during surface mining on the viability of VA mycorrhiza. Soil Sci. 129:253-257. 
Schuman, G.E., M.A. Stanley, and D. Knudsen. 1973. Automated total nitrogen analysis of soil and plant samples. Soil Sci. Soc. Amer. Proc. $37: 480-481$.

Schuman, G.E., E.M. Taylor, Jr., F. Rauzi, and G.S. Howard. 1980. Standing stubble versus crimped straw mulch for establishing grass cover on mined lands. J. Soil and Water Cons. 35:25-27.

Smith, P.L., E.F. Redente, and E. Hooper. 1987. Soil organic matter pp. 185-214. In: R.D. Williams and G.E. Schuman (eds.) Reclaiming minesoils and overburden in the western United States: Analytical parameters and procedures. Soil Conservation Soc. Amer., Ankeny, Iowa.

Stahl, P.D., S.E. Williams, and M. Christensen. 1988. Efficacy of native vesicular-arbuscular mycorrhizal fungi under severe soil disturbance. New Phytol. 110:347-354.

Stahl, P.D., G.E. Schuman, S.E. Williams, and S.M. Frost. 1996. Influence of arbuscular mycorrhiza on water stress tolerance of big sagebrush seedlings. Agron. Abst. p. 232.

Stahl, P.D., G.E. Schuman, S.M. Frost, and S.E. Williams. 1998. Interaction of arbuscular mycorrhiza and seedling age on water stress tolerance of Artemisia tridentata ssp. wyomingensis. Soil Sci. Soc. Amer. J. (in press).

Sturges, D.L. 1977. Soil water withdrawl and root characteristics of big sagebrush. Amer. Midl. Nat. 98:257-274.

Sylvia, D.M. and S.E. Williams. 1992. Vesicular-arbuscular mycorrhizae and environmental stress. In: Mycorrhizae in sustainable agriculture. Am. Soc. Agron. Special Publ. 54., Amer. Soc. of Agron. Madison, Wisc.
Sylvia, D.M., L.C. Hammond, J.M. Bennett, J.H. Haas, and S.B. Linda. 1993. Field response of maize to a VAM fungus and water management. Agron. J. 85:193-198.

Tessman, S.A. and L.H. Kleinman. 1989. Should the mining industry be required to increase the amount of sagebrush planted at reclaimed sites-point/counterpoint. The Wyoming Mining Claim. 15(2):8-11.

Walton, T.P., R.S. White, and C.L. Wambolt. 1984. Artemisia reproductive statregies: A review. pp. 67-74. In: Proc., Symposium on the biology of Artemisia and Chrysothamnus. 9-13 July 1984, Provo, Utah. Intermountain Res. Sta., Forest Service, USDA, Odgen, Ut.

Williams, S.E., M.A.J. Loree, and P.C. Singleton. 1981. The effect of long term storage on fertility and biological activity of topsoil. Abstract. In: Proc. of the Fifth North American Conf. on Mycorrhizae. August 1981, Quebec City, Quebec, Canada.

White, J.A., L.C. Munn, and S.E. Williams. 1989. Edaphic and reclamation aspects of vesicular-arbuscular mycorrhizae in Wyoming Red Desert soils. Soil Sci. Soc. Amer. J. 53:86-90.

Wyoming Department of Environmental Quality, Land Quality Division. 1996. Coal rules and regulations, Chapter 4, Appendix $A$, State of Wyoming, Cheyenne, Wyo

Young, J.A. and R.A. Evans. 1989. Dispersal and germination of big sagebrush (Artemisia tridentata) seeds. Weed Sci. 37:201-206. 